\title{
Od proletariatu do prekariatu, czyli o kierunku rozwoju prawa pracy
}

W 1984 r., czyli ponad 30 lat temu, odbył się VII Zjazd Katedr Prawa liński. Czasy były trudne politycznie i ekonomicznie, a $\mathrm{w}$ trakcie obrad dyskutowaliśmy, czy zmierzamy do rozwoju prawa pracy, czy w związ$\mathrm{ku} \mathrm{z}$ wprowadzaniem elementów cywilnoprawnych do stosunku pracy idziemy w kierunku regresu tej gałęzi prawa. Owe elementy cywilne były $\mathrm{w}$ tamtym czasie znikome (zakładowe systemy gospodarcze, premie z zysku), ale i tak budziły namiętności i spory. Zdania były podzielone, przeważał jednak pogląd, że cywilistyka promuje indywidualizm. Aktualnie też spotykamy rozwiązania rodem z prawa cywilnego, ale mierzymy się z zupełnie nowymi zjawiskami na rynku pracy, a gospodarka rynkowa wykształciła u pracodawców, może nadmierne, myślenie o własnym tylko zysku i kształtowanie warunków wynagradzania (premiowania) w zależności od efektu gospodarczego, jaki przynosi pracownik. Ponadto dzisiejszy pracodawca nie przyjmuje na siebie ryzyka zatrudnienia, stąd ucieczka w takie jego formy, które nie są stabilne, dają możliwość łatwego rozerwania węzła obligacyjnego. $\mathrm{W}$ jakimś sensie pomaga mu $\mathrm{w}$ tym ustawodawca zezwalając na zatrudnienie tymczasowe i na pracę na zastępstwo. W jakim zatem aktualnie zmierzamy kierunku?

Zacznijmy od genezy prawa pracy. Jak wiadomo zaczęło się ono wykształcać się w wieku XIX pod wpływem zmiany stosunków społecznogospodarczych i prawnych. Zmiany te urzeczywistniały porządek prawny i gospodarczy oparty na wolności, rozumianej jako niczym nieograniczone korzystanie $z$ własności. Prowadziło to do powstawania nowych form zależności, wyzysku i nierówności społecznej, wprowadzanych pod hasłem stałego obniżania kosztów. Warunki pracy układały się jako wynik w żaden sposób nieskrępowanej gry rynkowej: podaży i popytu na pracę.

* I Prezes Sądu Najwyższego, profesor w Katedrze Prawa Pracy i Polityki Społecznej Uniwersytetu Warszawskiego. 
W tym okresie pojawili się ludzie żyjący tylko z pracy rąk bez kapitału, którzy byli słabi ekonomicznie. Powstał proletariat, który zaczął dążyć do organizowania się w zrzeszenia pracownicze oraz walczyć o ustawodawstwo ochronne.

Prawo pracy stawało się dziedziną przepojoną elementami publicznoprawnymi oraz wykorzystującą wiele nowych instytucji prawnych (układy, spory zbiorowe). Mimo to do początku wieku XX prawo pracy rozwijało się $\mathrm{w}$ ramach prawa cywilnego i prawa administracyjnego, nie stanowiąc odrębnej gałęzi prawa. Dopiero po pierwszej wojnie światowej zaczęto uznawać, że przedmiot regulacji (praca umownie podporządkowana) uzasadnia konieczność wyodrębnienia samodzielnej dziedziny prawa i nauki prawa. W Polsce w latach trzydziestych ubiegłego stulecia powstawały akty prawne poświęcone regulacji stosunków pracy, natomiast formalnie odrębność prawa pracy została uznana przez ustawodawcę dopiero z dniem wejścia w życie ustawy - Kodeks cywilny z 1964 r. (patrz art. XII § 1 ustawy z 23 kwietnia 1964 r. - Przepisy wprowadzajace Kodeks cywilny ${ }^{1}$ ). Obecnie potwierdzenie odrębności prawa pracy od prawa cywilnego znajdujemy w przepisie art. 300 k.p.

Od początku wieku XX prawo pracy zaczyna podążać w kierunku poszerzenia zakresu przedmiotowego regulacji prawnej. Drugim nurtem rozwoju prawa pracy wieku XX jest tworzenie podstaw współdziałania załogi w zarządzaniu, swobodnego rozwoju związków zawodowych, układowej regulacji stosunków pracy, rozstrzygania sporów zbiorowych zgodnie z zasadą równości partnerów socjalnych, rozwój przedstawicielstw załogi (rady pracownicze) i rozszerzenie ich kompetencji. Tendencje te są rozwijane przez Radę Europy i standardy europejskie uchwalane przez UE, które statuują coraz wyższy poziom ochrony socjalnej dla zatrudnionych, wskazują na konieczność regulacji prawnej nowych zjawisk występujących na rynku pracy, takich jak dyskryminacja, mobbing, zatrudnienie niepełnosprawnych, zrównanie szans zawodowych i socjalnych wszystkich obywateli zjednoczonej Europy; wskazują na konieczność ochrony wynagrodzenia pracowniczego także $\mathrm{w}$ okresie niewypłacalności pracodawcy. Widoczna jest również $w$ tym rozwoju chęć upodmiotowienia nie tylko związków zawodowych, lecz także załogi. Zwraca się zatem uwagę na konieczność uwzględniania prawa załogi do informacji, na regulację prawną praw załogi w korporacjach o zasięgu międzynarodowym.

W Polsce od lat dziewięćdziesiątych ubiegłego stulecia obserwujemy i wdrażamy w życie standardy UE. Stosunki społeczno-gospodarcze zmieniają się, a za nimi podążają zmiany prawa, w tym prawa pracy. I tak po 1989 r. mieliśmy ustanowione przepisy o zwolnieniach grupowych, odprawach, powszechnym funduszu socjalnym, wcześniejszych emery-

${ }^{1} \mathrm{DzU}, 1964, \mathrm{nr} 16$, poz. 94 ze zm. 
turach, emeryturach pomostowych, zasiłkach dla bezrobotnych. $\mathrm{W}$ dobie rozwijającej się i prosperującej gospodarki było to możliwe. Uznano, że żyjemy w dobie rozwijającej się gospodarki i można odstąpić od wielu regulacji ochronnych na rzecz form cywilistycznych w celu wspierania konkurencyjności przedsiębiorstw poprzez obniżenie kosztów pracy. Zaczęto mówić o konieczności liberalizacji prawa pracy, i potrzebie jego zwrotu w stronę cywilistyki.

Kryzys gospodarczy powinien zmienić optykę ustawodawcy. Tak jednak się nie stało. Przepisy ochronne zaczęły bowiem ewoluować w kierunku ograniczenia ochrony pracy pod hasłem elastyczności zatrudnienia i konkurencyjności na rynku pracy. Zmniejszają się odprawy z tytułu zwolnień grupowych, modernizują emerytury, aż po podniesienie wieku emerytalnego dla wszystkich. Stale rośnie bezrobocie. Także bezrobocie wśród młodzieży. A według najnowszych badań amerykańskich wzrost bezrobocia unieszczęśliwia społeczeństwo pięć razy bardziej niż wzrost inflacji. Stoimy przed wielkimi wyzwaniami i walką o młodzież, która chce wyjechać za granicę „za chlebem”.

Potrzeba zmian prawa pracy związanych z kryzysem została wreszcie dostrzeżona przez media. Coraz częściej zwracają one uwagę na nietypowe formy zatrudnienia mówiąc nie o koniecznej liberalizacji, ale wypowiadając się pejoratywnie np. o tzw. umowach śmieciowych, mając na myśli tak terminowe umowy o pracę, umowy na zastępstwo, jak i umowy cywilne. Już w tym miejscu wypada skonstatować, że nadmierne wykorzystywanie tych umów w dużej mierze jest skutkiem działań pracodawców, którzy zmierzają do ograniczania kosztów pracy przez zmniejszanie zobowiązań podatkowych, składkowych etc. Socjologowie pracy stwierdzaja, że dzisiejsze stosunki zatrudnienia prowadzą nieodwracalnie do tworzenia się ponownie klasy pracujących dorywczo - prekariuszy. Nie mają oni żadnej stabilności zatrudnienia. Zostają wykluczani z ochrony pracy. Zataczamy zatem niebezpieczne koło od XIX-wiecznego proletariatu do prekariatu wieku XXI. Jest to trudne do zaakceptowania i wymaga natychmiastowej interwencji ustawodawczej, co będzie oznaczało większy wpływ prawa publicznego na stosunki pracy. Czy się na to godzimy po wieloletniej walce o ucywilistycznienie prawa pracy, to kwestia do szerszej dyskusji.

Inicjując tę dyskusję należy zwrócić uwagę na konieczność ponownego przeanalizowania przedmiotu prawa pracy i skierowania go w kierunku nowego prawa, prawa zatrudnienia dla wszystkich żyjących z pracy rąk. Aby nie powielać poglądów, które już prezentowałam w literaturze przedmiotu, chcę tylko podkreślić, że nie wystarczą drobne korekty Kodeksu pracy, lecz wymagane są zmiany $\mathrm{w}$ kierunku rozszerzenia ochrony na zatrudnienie niepracownicze oraz korelacji stosunków zatrudnienia z prawem podatkowym, które musi być stabilne w pewnej perspektywie czasowej. 
Niezależnie od zmian w prawie pracy trzeba skorygować ustawodawstwo zwalczające bezrobocie (elastyczne zatrudnienie, idea społeczeństwa opartego na wiedzy, wszystkie instrumenty przeciwdziałające wykluczeniu z rynku pracy) i przeciwdziałające skutkom starzenia się społeczeństwa (przedłużanie zatrudnienia, eliminowanie przedwczesnych świadczeń socjalnych, usuwanie barier socjalnych i podatkowych w kontynuacji zatrudnienia przez osoby starsze, kształcenie ustawiczne, opóźnianie wieku emerytalnego). Powstaje też konieczność dostosowania regulacji prawnych prawa pracy do zmian technicznych zachodzących w społeczeństwie (nie chodzi tu tylko o regulację pracy na odległość, ale także o ochronę prywatności pracownika i rozwój badań nad pisemnością umów).

Praca legislacyjna nie jest łatwa do wykonania. Aby ją przeprowadzić na wstępie należy dokładniej opisać te elementy prawa pracy, które kształtują status pracownika uznawany za zbyt ochronny, i przeciwstawić im status samozatrudnionego, który, co prawda, nie jest chroniony, ale jest ekonomicznie skuteczny i konkurencyjny na rynku. W literaturze postuluje się, by skonfrontować aspekty prawa pracy dotyczące "dobrobytu” pracowników z tymi, które przynoszą skuteczność ekonomiczną. Wydaje się przy tym, że nie trzeba popierać działań nakierowanych na tradycyjne formy ochrony, związane z każdą możliwością zatrudnienia, lecz budować mechanizmy wsparcia ekonomicznego dla wszystkich możliwych typów (form) zatrudnienia i oferować je każdemu chętnemu do pracy.

W Polsce (i w innych krajach) trwa debata o potrzebie istotnych zmian w uregulowaniu zatrudnienia i ubezpieczenia społecznego. Podejmowana jest zwykle z pozycji polityki społeczno-gospodarczej. Mniej natomiast uwagi poświęca się trudnym zagadnieniom prawnej konstrukcji zmian postulowanych $\mathrm{w}$ prawie, czyli problematyce rekonstrukcji zatrudnienia i ubezpieczenia społecznego, oraz wprowadzeniu i zdefiniowaniu kluczowych pojęć prawnych. Pisze się o tym, że szerokie rozumienie zatrudnienia wymaga podziału i kategoryzacji umów o zatrudnienie, a nie zamkniętego katalogu umów o pracę. Może już czas dołączyć do tej poważnej debaty.

\section{From Proletariat to Precarious Employment - Labour Law Development Directions}

\section{Summary}

During the VII ${ }^{\text {th }}$ National Labour Law Congress in 1984, in politically and socially difficult times, the discussion concerned civil law instruments' implementation into labour law. They were really few but a threat of regression of the system worried a lot. Nowadays, 
apart from such instruments we face new phenomena in the labour market such as focusing on the effect of work and its instability. The question what direction labour law is willing to develop strongly arises.

In a historical process it has passed a long way from liberalism, being imbued with public law elements, increasing role of collective relations and recently - EU introduced institutions. Then, after 1989, the market economy again demanded liberalization and civil law instruments. It had been possible before again the crisis came with more need for protection. Massive use of non-typical, precarious employment forms in such circumstances, leads dangerously to re-creation of XIX proletariat.

All this rises a need for discussion on the general reform of the regulation, not only amending the Labour Code, but creating all-employment law instead. Separately a new solutions should be adopted as to unemployment problem and the effect of ageing of society as well as new technologies impact on labour relations. Such a debate not only should focus on particular problems, but a manner of legal regulation, so difficult in a sphere of redefined employment institutions and definitions, as well. 